\title{
PERSPECTIVES OF POST-CONFLICT ENGAGEMENT AS AN ESSENTIAL MECHANISM FOR GLOBAL PEACE
}

\author{
Gjorgji Veljovski, M.A. \\ Military Academy "Gen. Mihailo Apostolski", Skopje \\ E-mail: gveljovski@yahoo.com
}

\begin{abstract}
:
The post-conflict engagement to secure stable and lasting peace is not a new concept, as historically the hostilities almost never ceased with the end of the war. However, the changing role of international community, the development of human rights, international laws, enhanced by the effects of globalization changed the nature of post-conflict engagement. Today we witness tremendous efforts from the international community to build, sustain, and sometimes even enforce peace throughout the world. There is a growing trend of international responsibility for global security, which initiated the concept of the global response to prevent escalation of violence in the war-torn societies. The post-conflict operations are becoming a doctrinal trend and the future mechanism to guarantee regional and global stability. Their essence is to tackle the roots of the conflict, not its symptoms. If properly applied, such tool is essential for ensuring global reconciliation and stable world peace. Being far from unmistakable in their decisions and actions, the Western democracies have so far demonstrated leadership in pursuing the idea of global peace through post-conflict engagement.
\end{abstract}

Keywords: war, post-conflict, international community, intervention, peace enforcement.

\section{Introduction}

Many historical examples have proven that achieving military objectives does not necessarily mean achieving a political end state. In the $19^{\text {th }}$ century, Carl von Clausewitz defined war as a continuation of politics by other means, which is still a relevant notion in the contemporary global battlefield. Even when the military actions are finished, the politics never stops (Jackson, 2013:96), and the military power remains to embody the latent danger for enforcing policies with deliberate violent means.

The concept of post-conflict operations is directly linked to causality between war and politics because they take place in the transition period in the conflict aftermath when there is a significant shift in choosing the types of ways and means necessary to achieve the ends. When the 
politics exhausts all efforts to achieve the desired ends peacefully, policymakers may decide to apply a military force that will use armed violence to impose the will on the opponent (Clausewitz, 1976:75). Once the opponent submits to the will of the initiating force, the politics again will take over and proceed with other, nonviolent ways and means.

However, it is a historical fact that the end of the war rarely means permanent termination of hostilities (Pillar, 1983:30-39). After the end of the war is declared, the conflict enters the post-conflict phase in which political ways and means take over. The role of the military force is to remain vigilant and ready to use violence if required, in order to secure the implementation of post-war policies. Today, the post-conflict operations have become a trend of modern warfare and a tool for securing permanent regional and global peace.

The roots of violence are usually the globalization forces and the new demands of the economic liberalization, not ethnicity and religion. The weakening of the financial and political capabilities of the fragile states is the cause of social crises and the imbalance of the ethnically heterogeneous societies that have previously been relatively stable (Crawford and Lipschutz, 1998). This makes the shift of power to be perceived as ethnic or religious discrimination. In postconflict management and transition in peace, it is necessary to apply appropriate security policies not only to restore society in a normal course but also to prevent a further escalation. This is why the core of post-conflict operations is strengthening institutions as pillars of the society. Providing security, social and economic essentials for the population are crucial to achieving lasting peace.

\section{Historical Overview of the Concept}

Some forms of post-conflict engagements could be traced deep into military history, probably because of guerrilla warfare. Unlike the conventional conflicts in which the war would have ended after one or several decisive battles, in the conflicts where insurgencies were involved, the hostilities rarely ended permanently. In many cases, peace was unstable and the use of military force was necessary to prevent rebellions. For example, most of the time inside the borders of the Roman Empire there was some sort of post-conflict operations to maintain the peace. Except during the period known as Pax Romana, the people in the conquered territories continued to resist. For centuries, the Roman military was constantly engaged in suppressing rebellions and control of the population. Similar to this, the European colonial powers constantly had to quell rebel movements during the colonial period because uprising and rebellions almost never stopped (Adolf, 2009:143-150). This is the main argument why larger countries in particular, have more experience in post-conflict engagements. It was acquired for centuries throughout many regions around the world and it is deeply embedded in their military culture.

This means that the use of military force or the threat of using the military force, once the war is over, is not a new concept (Rotermund, 1999:1-6). The novelty today comes from the structure of modern society, international law, human rights and the civilized achievements in general, where there is a much greater responsibility of the states for the global security. Today's post-conflict operations have completely different character as they aim at peace enforcement 
with minimal necessary force, and they are primarily designed to apply a wide range of non-violent means and methods (Marten, 2004:61).

The first time when a genuine collective responsibility was applied in the international relations was after the Second World War. Although Germany was defeated in the First World War, its aggressive policies resurrected for a reason. The conditions under which Germany was punished with the Treaty of Versailles triggered the German nationalism and fascism (Bendersky, 2007:33). Germany was cornered in a humiliating situation, which consequently turned the country from a victim to a predator, making the nationalists pursue the so-called German "living space" (Lebensraum) (Gonen, 2000:99-105). Therefore, after the Second World War, the allies led by the United States (US) decided to take serious steps forward in preventing Germany to end again in a humble and hopeless position. That could have created conditions that would force the Germans to seek revenge in the next war. The implementation of the Marshall Plan to assist the economies in Western Europe including Germany is considered as the beginning of a modern post-conflict concept in which permanent peace was achieved through reconstruction of the whole society (Hogan, 1987:26-53).

The US was the key actor that initiated the reconstruction of Germany from the ashes and helping it reintegrate with dignity. As opposed to the Treaty of Versailles, the idea was not to blame the entire population for the war. Although since 1945 the mission significantly changed, there is still a US military presence in Germany (and Japan). However, the main characteristic of this type of post-conflict presence is that it took place in countries where foreign forces have been accepted and there was no further resistance against them.

In contrast, there are other types of post-conflict operations when hostilities continue in some other form, from passive resistance to open rebellion. In such an operational environment, it is preferable that the foreign forces deployed for the purpose of peacebuilding, first cease hostilities and then proceed with the reconstruction. The contemporary post-conflict operations as in Afghanistan demonstrate that this could be done simultaneously. While the military forces are primarily used to suppress the Taliban, wide range of other policies are implemented to strengthen the society necessary to achieve lasting peace. These activities include necessary investments to reconstruct and build institutions, infrastructure, and public services.

After the Second World War, the United Nations (UN) was established to replace the ineffective League of Nations. Since then, the UN recognized and sponsored the concept of postconflict engagements as a tool to terminate the war. The UN became an important organization for the global projection of peace with a mandate to use various kinetic and non-kinetic ways and means for the purpose of peace enforcement, peacekeeping, and peacebuilding. The UN forces, the so-called "blue helmets", is probably one of the strongest mechanism of the international community to mitigate the consequences of war, helping countries involved in a conflict and guaranteeing peace after the conflict ends. 


\section{An Era of Post-Conflict Operations}

The wars or conflicts end at the negotiating table with a peace agreement. Only in rare cases, there is no need for the international community to intervene, control or guarantee the implementation of such agreement. After the Second World War, due to the changing role of the international relations and the establishment of the UN, the international community became actively involved in a reconciliation of the post-conflict regions (Thakur and Schnabel, 2001:4).

The peacekeeping is one of the main policies that the international community is implementing in the post-conflict situations in order to ensure or control the achieved peace agreement (Sheeran, 2015:102). There are many tools to enforce the peacekeeping policies, like financial support of the war-torn society, building institutions, organizing elections, helping governments in governance, social development, education, humanitarian aid, etc., but also an actual presence of military forces under the flag of the UN or other international coalition or alliance, to keep the peace with force if necessary.

The first type of UN peacekeeping mission was a monitoring role approved in 1948 in the Middle East to supervise the termination of the hostilities after the first Arab-Israeli war (Chandra, 2006:1-6). After the Second Arab-Israeli war, during the so-called Suez crisis, the idea of UN peacekeeping military force was conceived (the deployment of first "blue helmets"). The intervention of France, United Kingdom, and Israel after Egypt nationalized the Suez Canal, prompted discussion in the international community to deploy military forces from other countries with the UN resolution and mission, in order to guarantee the achieved peace agreement (un.org, 2017a). Until today, the UN organized 69 peacekeeping operations, 56 of which since 1988 (un. org, 2017b). This means that the interest and influence of the international community to prevent escalation of conflicts around the world after reaching a peace agreement increased significantly in the post-Cold War period (Thakur and Schnabel, 2001:3).

An especially important mission for the development of peacekeeping was the engagement of blue helmets in the Balkans after the breakup of Yugoslavia. This was due to the fact that four decades after the end of the Second World War, Europe again faced bloody conflict with enormous destruction and casualties that was marked with serious human rights violations, like ethnic cleansing and genocide. The commitment of the international community was tested on several occasions because of numerous controversies over jurisdiction of the UN forces to prevent violence against civilians, often becoming the target of attacks themselves.

A moral dilemma emerged whether it is possible to conduct effective peacekeeping without using raw military force. After NATO took its role seriously in Bosnia and Herzegovina in 1994, the peacekeeping operation turned into a peace enforcement operation (Hendrickson, 2006:61). At first, a no-fly zone was declared over Bosnia and Herzegovina, and then the mission expanded including the use of force against the Bosnian Serbs. Such a decisive action imposed the Dayton peace agreement for Bosnia and Herzegovina. Arguably, this was significant because it demonstrated that in desperate cases it is necessary to use violence to achieve peace. The failure of the UN peacekeeping force justified the use of NATO military force, creating new role 
and purpose for the existence of the alliance after the collapse of the USSR (Moore, 2007:28-29).

The peace enforcement, as opposed to peacekeeping, requires a much larger military force to make one, both or all sides in the conflict to accept and implement the peace agreement. Compared with the peacekeeping mission that could stretch for decades, the duration of peace enforcement is relatively short and more decisive because of the actual application of raw force. The UN Security Council may approve the peace enforcement operations, but sometimes it could be unilateral or a coalition-led by a stronger actor. This is often a controversial topic in the international law since it overlaps with the concept of military intervention to terminate a war only after a military victory is achieved. For the intervening force to impose peace, the opponent must be militarily defeated to accept some kind of peace agreement or conditional ceasefire. This means that not all countries have capabilities to enforce peace and such concept remains in the hands of several stronger international actors. However, in order to obtain legitimacy of such action, they will always aspire to gain international support and a resolution from the UN.

Currently, there are $14 \mathrm{UN}$ missions around the world (un.org, 2018c). Although in some of those countries it is peaceful for decades, the UN presence remains because of insufficient conditions to ensure lasting peace. This proves not only the post-conflict phases could stretch for a longer period, but also there is a necessity for the external, international intervention. This is the main reason why the post-conflict operations have become an elementary part of the military doctrines worldwide and a trend of the modern warfare. The dilemma is who should take a lead as a global peacemaker in a world that returned to bipolarity with signs of multipolarity. Not every large actor has capabilities and responsibilities in acting as a "world police", thus it is preferable that democracies enforce peace. So far, the western countries demonstrated the strongest dedication to invest in global peace through intervention in post-conflict regions.

\section{Stability Operations as a More Decisive Concept for the Post-Conflict Engagement}

While peacekeeping and peacebuilding are traditionally UN-led activities, the peace enforcement may be either an UN-led or coalition based. In both cases, it takes at least one strong actor as a leading nation that actually has physical force to impose peace. The explanation why the US and its NATO allies agreed on the concept of peace enforcement through intervention is the perception of inert and indecisive action of the UN-led operations.

In the early $90 \mathrm{~s}$, the US augmented the post-conflict engagements designed as peace operations (keeping, making, and building) with the concept of peace enforcement. This was developed at first as "military operations other than war". After the intervention in Iraq in 2003, the terminology changed to "stability and support operations". The concept later evolved as peace support operations and today the doctrinal term is "stability operations". The US military introduced this doctrine to deter war through intervention, resolve conflict, promote peace, and support civil authorities in response to domestic crises. It was meant to include many tasks that are nonviolent but use the threat of force to achieve the goals. The more recent update defines "stability" a combination of both military and nonmilitary efforts and coordination of all instruments of 
national power, to "address drivers of conflict, foster host-nation resiliencies, and create conditions that enable sustainable peace and security" (Pub, 2016:IX) and "maintain or reestablish a safe and secure environment, provide essential governmental services, emergency infrastructure reconstruction, and humanitarian relief" (Pub, 2016: I). Peace enforcement is the typical tool that these operations use to tackle violence, usually by use or threat to use force. It demonstrates the US capabilities when diplomatic means are not sufficient to resolve the crisis. As described in the US Joint Doctrine, these low intensity military operations cover all peace operations, protection of shipping, enforcement of sanctions and maritime intercept operations, enforcing exclusion zones, ensuring freedom of navigation and overflight, humanitarian assistance, arms control, support to civil authorities, nation assistance, and evacuation operations (Pub, 1995:IX). Such post-conflict activities usually start with military involvement and end with civilian dominance. As soon as the intervention forces eliminate the threat of violence, they shift on activities such as rebuilding civil infrastructure and institutions, a transition to domestic authorities, reestablish a government and support truce and negotiations (Pub, 1995:IV-12). An important task in stability operations is to prevent civilians, especially in ethno-religious conflicts, to interfere the operations. An example of failure to prevent this was the escalation of the ethno-sectarian strife in Iraq in 2006 between Sunni and Shia.

The US as a global actor influence stability in regions through overseas demonstration of commitment and support to civil authorities of allies before, during and after a crisis occurs. The preferable way to avoid the use of force is deterrence. If this fails, the US doctrine justifies the use of force to "compel compliance in the form of strikes, raids, peace enforcement, counterterrorism, enforcement of sanctions, support to insurgency and counterinsurgency, and evacuation of noncombatants" (Pub, 1995: VIII). The stability operations are the most decisive form of postconflict engagement because they include both kinetic and non-kinetic methods across the spectrum of conflict. A critique of this concept is that the term "stability" is a euphemism for operations that are still primarily military in nature, and such interventions in the opposite of UN missions, may occur without a full consensus of the international community, or the UN Security Council.

\section{Challenges and Future Development}

Due to globalization and interdependent international relations, ethno-religious clashes in particular, are considered the most serious threat to regional and global stability. One of the biggest challenges in the post-conflict societies is the national reconciliation among conflicted parties. As today's conflicts are mostly ethno-religious, these two categories are also the most difficult to reconcile (Fox, 2002:143). They dig deep into the identity, the historical background and the collective memory of the people. The ethno-religious conflicts are far bloodier than ideologically motivated conflicts, inevitably accompanied by serious human rights violations such as ethnic cleansing, genocide, massacres and population displacement (Cordell and Wolff, 2010). As a rule, the greater the damage was, it takes more time to achieve reconciliation. 
An example for this was the war in Bosnia and Herzegovina where violence between the conflicting parties reached a critical point after which it took longer time for reconciliation. Twentytwo years later, there was still ongoing trial at The Hague International Criminal Tribunal for the former Yugoslavia. While simultaneously the mechanism for bringing all the accused war criminals to justice was necessary, stretching the trials indirectly contributed to prolonging the point of reconciliation because it keeps feeding the collective memories of the victims. Realistically, it will take a longer time to pass after all crimes are being sanctioned to reach the point of lasting reconciliation. This is the reason the international community should intervene before ethnic strife reaches the point of crossing the lines.

There are many cases when the international community is either passive due to the inconsistency of the interests of the global actors, or it is unable to act. An example of this is the post-conflict phase in the region of Nagorno-Karabakh where there is a virtually frozen conflict for more than twenty years. The international community is a passive observer, without taking any steps to solve the conflict and the status of internally displaced refugees in Azerbaijan. This is partially due to the influence of Russia in the region, but also because of lack of interest on the list of priorities. Some conflicts in the Third World are simply not of a high importance for the Western countries. Unlike in Rwanda where the international community failed to stop the genocide of 800.000 people (Melvern, 2004:252; Cohen, 2007:5), it reacted far more decisively in Bosnia and Herzegovina and Kosovo simply because they are on European soil.

In post-conflict societies, there might be an absence of war, but not the conditions for lasting peace. This implies there are many factors that could lead to disruption of balance established with the peace agreement, or disruption of economic and social conditions may contribute to reducing hostilities. The function of the post-conflict operations is to predict and prevent these elements that lead to the previous stage of armed violence. This requires the establishment of viable, lasting institutions that will ensure stable civil services and long-term security in the war-torn society. The UN primarily leads the post-conflict efforts today (un.org, 2017) because in most cases an international consensus is necessary to implement legal and sustainable policies. Besides military ways and means, this also includes various political, economic and informational efforts to strengthen the national power of the country once peace was achieved. The international community facilitates the conditions for permanent peace to overcome the possible conflicting scenarios by building lasting and sustainable capabilities through multiple mechanisms. Peacebuilding in the post-conflict societies requires great commitment and allocation of resources to implement a wide range of policies such as reintegration of fighters of conflicting parties, the return of refugees, organizing elections, assisting the establishing of state institutions, and avoiding political disputes, which may lead to a reinstatement of violence, ect.

In the future, it is expected that the western democracies will continue with the practice to intervene in post-conflict scenarios. In such engagements, NATO or US-led coalition forces would influence the operational environment with the decisive use of military force, if necessary. The main purpose of these engagements will be securing stable peace through aiming at specified illegal activities, deter or defeat hostilities, maintain or restore order in restless areas, facilitate 


\section{Security}

diplomacy, enforce agreements and policies and support weak governments (Global security org.). This will most likely include various activities to provide security, humanitarian assistance, economic stabilization and building infrastructure, deliver rule of law and governance to civilian authorities of the host nation (Pub, 2016:xii).

The reason the international community (predominantly the Western democracies) is actively involved in post-conflict operations are the effects of the globalization or the view that instability, crises, and wars in some regions inevitably will affect the global peace and security. Whenever conflicts were left alone it turned out to generate harmful consequences that were felt beyond the crisis regions. Without international support, the conflicts would be far more dangerous with a tendency to spread, so the concept of post-conflict engagement is actually the international community's preventive strategy to achieve global peace and security.

\section{Conclusion}

The history is overwhelmed with examples that after wars formally ended hostilities remained. The winning side still had to use force to prevent de-escalation, especially during the colonial era in many counterinsurgency campaigns. The fact that hardly anyone was able truly to defeat the insurgencies, suggest the improper approach of the winning side in the post-conflict phase of the war. Even the greatest empires succumbed to grueling counterinsurgency campaigns. It took a long time to realize that it is necessary to change the operational approach in a postconflict phase of the war.

The modern concept of building stable peace comes from the postwar construction of Western Europe. In order to ensure lasting peace, the western democracies determined that it is necessary to invest in building societies to improve the quality of living as the main reason for people's discontent after the war. This approach to creating conditions to support reconciliation especially becomes a trend after the establishment of the UN and its involvement in many postconflict situations. The new paradigm in global security appeared with the disintegration of Yugoslavia and the Balkan ethnic wars when the UN blue helmets were put on a test. Due to the lack of decisiveness and much controversy over jurisdiction, a security gap was created and the belligerents ignored the UN efforts. In 1994, NAT0 took the lead with a military intervention to enforce the peace in Bosnia and Herzegovina. After signing the peace agreement, the international community remained in the country for peacekeeping and peacebuilding for years. The lessons from the Second World War to invest in lasting peace were successfully applied in Bosnia and Herzegovina.

This was the beginning of a trend that in the post-conflict regions it is required to maintain the military presence and if necessary to use it to secure the peace. The responsibility lies with the international community and the global actors that have capabilities for the expensive peacebuilding. While the UN remains the primary organization currently present in 14 postconflict missions, the practice shows that NATO as the representative of the Western democracies also assumes an important role to project global peace. In the Western military doctrines, stability 
operations became the new concept for post-conflict engagement to reconcile and prevent hostilities to escalate. Until a better solution is found, the application of force through intervention will remain the preferred tool to secure global peace. Although being far from unmistakable in their decisions and actions, the Western democracies remain as leaders in providing this.

\section{References}

1. Adolf, A. (2009). Peace:A World History. Cambridge: Polity Press.

2. Bendersky, J.W. (2007). A Concise History of Nazi Germany. Third edition, Lanham: Rowman \& Littlefield Publishers Inc.

3. Chandra S. Chandra M. (2006). International Conflicts and Peace Making Processs: Role of the United Nations. New Delhi: Mittal Publications.

4. Cohen, J. (2007). One-hundred Days of Silence: America and the Rwanda Genocide. Rowman \& Littlefield Publishers Inc.

5. Cordell K. Wolff S. (2010). Ethnic Conflict: Causes, Consequences, and Responses. Cambridge: Polity Press.

6. Crawford B. Lipschutz R.D. (1998). The Myth of "Ethnic Conflict": Politics, Economics, and "Cultural" Violence, Berkeley: University of California.

7. Fox, J. (2002). Ethnoreligious Conflict in the Late Twentieth Century:A General Theory. Lanham: Lexington books.

8. Conen, J.Y. (2000). The Roots of Nazi Psychology: Hitler's Utopian Barbarism. The University Press of Kentucky.

9. Hendrickson, R.C. (2006). Diplomacy and War at NATO: The Secretary General and Military Action after the Cold War. Columbia: University of Missouri Press.

10. Hogan, M.J. (1987). The Marshall Plan: America, Britain and the Reconstruction of Western Europe, 1947-1952. Cambridge: Cambridge University Press.

11. Jackson, R.J. (2013). Global Politics in the 21st Century. Cambridge: Cambridge University Press.

12. Manifred K. Rotermund. (1999). The Fog of Peace: Finding the End-State of Hostilities. The Strategic Studies Institute, Carlisle:US warCollege, available at:https://ssi.armywarcollege. edu/pdffiles/PUB305.pdf.

13. Marten, K.Z. (2004). Enforcing the Peace: Learning from the Imperial Past. NY: Columbia University Press.

14. Melvern, L. (2004). Conspiracy to Murder: The Rwandan Genocide. London: Verso.

15. Moore, R.R. (2007). NATO's New Mission:Projecting Stability in a Post-Cold War World. London: Praeger.

16. Paret, P. (1985). Clausewitz and the State: The Man, His Theories, and His Times. Princeton: Princeton University Press.

17. Pillar, P.R. (1983). Negotiating Peace: War Termination as a Bargaining Process. Princeton: Princeton University press. 


\section{Securrity}

18. Pub, J. (1995). Pub 3-07, Joint Doctrine for Military Operations Other Than War. Washington $D C$ : Joint Chiefs of Staff.

19. Pub, J. (2016). Pub 3-07, Stability. Washington DC: Joint Chiefs of Staff.

20. Sheeran, S. (2015). "UN Peacekeeping Safety and Security in the $2^{\text {lst }}$ Century: Towards an Agenda of Reform". In: Powles A. Partow N. \& Nelson N (eds), United Nations Peacekeeping Challenge: The Importance of the Integrated Approach, London: Routledge.

21. Thakur, R.C. and Schnabel, A. (2001) (eds). United Nations Peacekeeping Operations: Ad Hoc Missions, Permanent Engagement, Tokyo: United Nations University Press.

Websites:

1. Global security org, https://www.globalsecurity.org/military/ops/saso.htm

2. UN Resolution 1001, http://www.un.org/depts/dhl/dag/docs/ares1001e.pdf

3. UN peacekeeping. History of peacekeeping, http://www.un.org/en/peacekeeping/ operations/history.shtml

4. UN peacekeeping.Currentpeacekeeping operations, http://www.un.org/en/peacekeeping/ operations/current.shtml

5. UN Support Peacebuilding and Post-Conflict Recovery. Office for ECOSOC Support and Coordination, http://www.un.org/en/development/desa/oesc/peacebuilding.shtml 